\title{
Sprawozdanie
}

\section{Transatlantyckie Forum Prawnicze „Konstytucjonalizm w kryzysie?”, Hamburg, 28 -29 października 2011 r.}

Już po raz piąty wiodące amerykańskie think tanki - American Enterprise Institute (AEI - www.aei.org), The Federalist Society (www.fed-soc.org) Rada Polityki Publicznej, działająca przy bawarskim Uniwersytecie w Bayreuth (www.council.uni-bayreuth.de) oraz pierwsza prywatna niemiecka szkoła wyższa prawa - Bucerius Law School - zorganizowały w Hamburgu w dniach 28-29 października 2011 r. Transatlantyckie Forum Prawnicze.

Odbywające się co roku wymiennie raz w Waszyngtonie, raz w Niemczech przedsięwzięcie tym razem poświęcone było globalnemu kryzysowi oraz związanym z nim wyzwaniom, z którymi mierzą się nie tylko konstytucjonaliści po obu stronach Atlantyku. Jak zauważyli organizatorzy konferencji, seria ekonomicznych oraz politycznych kryzysów, które miały miejsce w ostatnich latach, nakazuje zastanowić się, czy krajowe i międzynarodowe struktury prawno-polityczne i mechanizmy prawno-konstytucyjne nie okazały się nieefektywne i jako takie nie wymagają przemyślenia i głębokiej reformy. Co ciekawe, duża część omawianych problemów jest tożsama dla Stanów Zjednoczonych i Unii Europejskiej, czego dowodzi pilna potrzeba zmian choćby w systemach opieki zdrowotnej, socjalnej i emerytalnej związana $\mathrm{z}$ trudną sytuacją gospodarczą i demograficzną.

Program Forum został podzielony na sześć głównych paneli tematycznych zatytułowanych:

1. „Banki centralne, budżety i plany ratunkowe”,

2. „Czy konstytucjonalizm amerykański umarł?”,

3. "Sądy i konstytucje”,

4. „Czy konstytucjonalizm europejski umarł?”,

5. „Państwo socjalne, demografia i stabilność konstytucyjna”,

6. „Czy demokracje konstytucyjne w dalszym ciągu mogą być zarządzane?". 
Należy przyznać, że organizatorom udało się zaprosić do Hamburga wyjątkowe grono naukowców i praktyków z bardzo różnorodnych instytucji amerykańskich i europejskich, co ciekawe, nie wszyscy byli prawnikami i można było odnieść wrażenie, że właśnie ci wnieśli do dyskusji najwięcej.

W pierwszym panelu - moderowanym przez Clausa Tiggesa z niemieckiego Banku Federalnego - zasiedli m.in. Kenneth Dam ze szkoły prawa Uniwersytetu w Chicago oraz Charles Goodhart z London School of Economics. Głównym wątkiem dyskutowanym w tym bloku było trudne zadanie niezależnych banków centralnych, polegające na wypracowywaniu kompromisu pomiędzy zasadami demokracji i potrzebą utrzymywania stabilności polityki pieniężnej. Jak wskazywał jeden z panelistów, banki centralne są niedemokratycznymi instytucjami, których funkcjonowanie opiera się na wiedzy zarządzających nimi osób. Pytaniem retorycznym, które się narzuca choćby po kryzysie federalnych agencji Fannie Mae oraz Freddie Mac, brzmi, czy ktoś w ogóle ocenia poprawność realizowanych przez te osoby działań albo innymi słowy - czy np. amerykański FED czy Europejski Bank Centralny podlegają klasycznym zasadom obowiązującym w demokracji konstytucyjnej. Innymi słowy - kto sprawdza i kontroluje „kontrolerów" i czy brak kontroli nie sprzyja nadużyciom?

Drugi z paneli moderowany przez Leonarda Leo z The Federalist Society z udziałem m.in. Katji Gelinsky z Fundacji Konrada Adenauera oraz wieloletniego amerykańskiego dyplomaty Claylanda Boydena Graya poświęcony był radykalnym zmianom instytucjonalnym, które zaszły w Stanach Zjednoczonych $\mathrm{w}$ ciągu ostatnich 60 lat, przy równoczesnym braku odpowiadającym tym zmianom koniecznych korekt Konstytucji. Przykładem takich zmian jest właśnie powstawanie od czasów Nowego Ładu autonomicznych i podlegających bardzo słabej społecznej kontroli - agencji rządowych, które jednocześnie mają realne kompetencje do wpływania na całe dziedziny gospodarki. Również w tej materii konstytucyjna zasada checks and balances wydaje się w tym zakresie doznawać niepokojącego wyłomu.

W kolejnym - trzecim - panelu, moderowanym przez Inkę Hanefeld, Donald Horowitz z Uniwersytetu Duke oraz sędzia TS UE Endre Juhász dyskutowali o rosnącym znaczeniu politycznym sądów konstytucyjnych. Jednym $z$ dyskutowanych zagadnień była kwestia ochrony przez sądy konstytucyjne (jeden z panelistów za takowy uznał również ETPC) praw człowieka, ale i potrzeba dalej idącej wykładni znaczenia zasad - elementów podstawo- 
wego porządku konstytucyjnego państw, takich jak podział władz, suwerenność państw, dobro wspólne czy federalizm.

Czwarty panel poświęcony był problemom europejskiego konstytucjonalizmu. Christian Kirchner z berlińskiego Uniwersytetu Humboldta, Jeremy Rabkin z George Mason Law School, Krassen Stanchev - szef bułgarskiego Instytutu Gospodarki Rynkowej - dzielili się swoimi obserwacjami na temat zmian zachodzących w Unii Europejskiej po wejściu w życie Traktatu lizbońskiego. Najpoważniejszy od dziesięcioleci kryzys finansowy spowodował, że wielu europejskich decydentów (co ciekawe nie przedstawicieli samej UE) zaczęło forsować jeszcze dalej idące rewizje traktatów, dotyczące choćby polityki fiskalnej poszczególnych państw członkowskich. Jakkolwiek by te propozycje oceniać od strony efektywności ekonomicznej, trudno nie uznać ich za kolejny krok w ograniczaniu autonomii państw, może to też stanowić niekoniecznie pożądany precedens dla innych dziedzin.

Przedostatni panel, w którym uczestniczyli m.in. Vito Tanzi z Międzynarodowego Funduszu Walutowego, Michael Wohlgemuth z Instytutu Waltera Euckena oraz Michael Zöllner - szef Rady Polityki Publicznej - dotyczył tego, w jakim stopniu problemy trudnych w dalszym utrzymywaniu wysokich wydatków socjalnych państwa, proces starzenia się zachodnich społeczeństw i zmniejszania populacji stanowią wyzwanie dla porządku konstytucyjnego państw demokratycznych. Inne pytanie brzmiało, czy wprowadzenie/uzupełnienie konstytucyjnych regulacji mogłoby zapobiec nieefektywności zarządzania finansami oraz dalszym niepokojącym procesom skutkującym np. pogłębianiem się długu publicznego lub je ograniczyć.

Tytuł ostatniego panelu z udziałem Kennetha Minogue z London School of Economics, Alberta Mindardiego z Instytutu Bruno Leoniego oraz Henry'ego Olsena z AEI nawiązywał do toczonych w latach 70. ubiegłego stulecia w naukach politycznych dyskusji o osiągnięciu stanu braku możliwości dalszego zarządzania zachodnimi demokracjami (ungovernability) wskutek nieopanowanego rozrostu tzw. państwa dobrobytu. Zdaniem części panelistów - wyłączywszy krótkie okresy reform w Wielkiej Brytanii pod rządami Margaret Thatcher i w Stanach Zjednoczonych doby Ronalda Reagana - problem faktycznej „sterowalności” państw - demokracji konstytucyjnych w dalszym stopniu pozostaje niepokojąco aktualny.

$\mathrm{Na}$ marginesie powyższych rozważań warto zwrócić uwagę na fakt, że podczas Forum eksperci z obu stron Atlantyku podawali przykład Polski 
jako kraju, który nie tylko prowadzi wyważoną i mądrą politykę zagraniczną, uwzględniającą interesy suwerennego państwa w Europie, ale i mającego skuteczne konstytucyjne ramy i obostrzenia w zakresie finansów publicznych. Jest to o tyle godne uwagi, że poza niżej podpisanym brak było na Forum uczestników z naszej strony Odry.

Sukces konferencji to zasługa przede wszystkim prof. Michaela S. Greve absolwenta Uniwersytetu Hamburskiego od wielu lat pracującego w Stanach Zjednoczonych, wykładowcy wielu uniwersytetów i koordynatora wielu programów American Entrerprise Institute, w tym Transatlantyckiego Forum. Kolejne odbędzie się już jesienią w Waszyngtonie, zaś w przyszłym, 2013 r. będzie - miejmy nadzieję - kolejna okazja, aby wziąć udział w europejskiej edycji przedsięwzięcia.

Marcin Przybysz (Uniwersytet Szczeciński) 